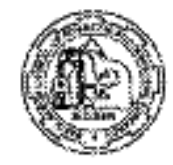

BCSIR
Available online at www.banglajol.info

Bangladesh J. Sci. Ind. Res. 44(1), 51-56, 2009
BANGLADESH JOURNAL OF SCIENTIFIC AND INDUSTRIAL RESEARCH

E-mail: bjsir07@gmail.com

\title{
Effect of Mulching Material on the Yield and Quality of Potato Varieties Under No Tillage Condition of Ganges Tidal Flood Plain Soil
}

\author{
M. A. Razzaque*a and M. A. Ali ${ }^{\mathrm{b}}$ \\ ${ }^{a}$ Regional Agricultural Research Station, Bangladesh Agricultural Research Institute \\ Rahmatpur, Barisal and ${ }^{b}$ Soil Resource Development Institute Farmgate, Dhaka
}

\begin{abstract}
The field experiment was carried out during rabi season of 1999-2000 to 2000-2001 with five recommended potato varieties viz. Heera, Dhera, Diamant, Chamak and Cardinal along with two types of mulching materials viz rice straw and water hyacinth to find out suitable variety (ies) and mulching material(s) for obtaining higher yield under no tillage condition. Heera produced highest yield under both rice straw (19.45 t/ha) and water hyacinth (23.15 t/ha) mulch. Rest of the variety performed more or less similar in both cases. Both Heera and Dhera seemed to be suitable for cultivation in no tillage condition.
\end{abstract}

Key Words: Potato varieties, Mulching material, Yield and Quality.

\section{Introduction}

Potato is one of the most important crops in Bangladesh. Owing to promotional effort of government it is being placed as a third crop next to rice and wheat (Haq and Matin. 2006). Potato is the third largest food crops of Bangladesh (Rashid, 1999). Every year in Bangladesh, the potato field becomes flooded and the floodwater especially in lowlying areas recedes from the field very late. Non saline phase of the Ganges tidal flood plain of southern region of Bangladesh comprise part of Barisal, Patuakhali, and
Barguna districts characterized by tidal flooding of field, high rainfall in monsoon and short winter. Rice is the main crops grown in the kharif season. During the rabi season, land mainly remain fallow. Reason for fallow in the winter season delay of harvest of transplanted aman rice and wetness of soil. Land becomes free and soils comes to working condition at the end of the November to first week of January which is the time not optimum for sowing of many rabi crops due to most of the land cultivated 
under local T. aman and this aman rice harvest up to 1st week of January. That is why; planting of potato following the traditional methods becomes delayed which directly affects the yield. Due to slow recession of floodwater, planting of seed tubers sometime is not possible even in the month of December (Hoque, 2001). The technology of potato cultivation without tillage has been developed for those areas (Rashid, 1999). In this method, whole tubers of potato are planted directly to the wet field immediately after removal of floodwater and then the field is covered by thick mulch (Annon. 2000). Thick mulch helps to retain sufficient moisture in the soil. Cut tubers should not be used in this method (Razzaque et al., 2000). In some areas of Bangladesh, farmers are practicing this technology but they are using different varieties and different mulching materials. No screening trials were conducted so far with the existing potato varieties that perform better under no tillage condition and also no mulching material was standardized. Some farmers use straw as mulch and some others use water hyacinth. They are also not aware of thickness of the mulch. For this reason they are not getting expected yield of potato. Hence, an investigation was undertaken with five recommended potato varieties and two mulching materials with the following objectives:

1. To find out suitable potato variety (ies) that perform better under no tillage condition and
2. To find out suitable mulching material(s) for obtaining higher yield in potato cultivation under no tillage condition.

\section{Materials and Methods}

The field trial was conducted at the farming system research site Lebukhali Patuakhali of Bangladesh Agricultural Research Institute (BARI), during the Rabi season of 19992000 and 2000-2001 having sandy loam soil. The experimental soil exists $\mathrm{pH}$ 6.3, Organic matter 0.95 (\%), K 0.58 (\%). Tubers of five recommended varieties of potato viz. Heera $\left(\mathrm{V}_{1}\right)$, Dhera $\left(\mathrm{V}_{2}\right)$, Diamond $\left(\mathrm{V}_{3}\right)$ Chamak $\left(\mathrm{V}_{4}\right)$ and Cardinal $\left(\mathrm{V}_{5}\right)$ along with two types of mulching materials viz rice straw $\left(M_{1}\right)$ and water hyacinth $\left(\mathrm{M}_{2}\right)$ were included for the study. The experiment was set up in randomized complete block design (RCBD) with three replications. The unit plot size was $6.0 \mathrm{~m} \times 4.0 \mathrm{~m}$. Immediately after recession of flood water, whole tubers were planted maintaining a distance between rows $60 \mathrm{~cm}$ and between plants $25 \mathrm{~cm}$. Potato was planted 7 December in both the years. Fertilizers were applied @ 330-220-250120-14-6 kg of urea, triple super phosphate (TSP), puriate of potash (MP), gypsum, zinc sulphate and boric acid per hectare respectively (Anon., 2002). Full amount of TSP, MP, Gypsum, Zinc sulphate, Boric acid and half of the urea were applied before planting by broadcast and properly mixed with soil so that the tuber does not come in contact with the fertilizers during planting. The remaining 
urea was top dressed before irrigation at around 30-35 days after planting. Before planting, shallow furrows were made by a stick where the tubers were planted in wet soils by placing them in the particular place and pressing slightly. After that, the plots were covered by thick mulch (6-8 inch). Irrigation water was sprayed over the field immediately after top dressing of urea. Weeding and other intercultural operations were done as and when necessary for raising the crop. The crop was sprayed with Redomeal MZ 72 and Dimecron to prevent diseases and insects. The dates of harvesting were 10th March 2000, respectively and 14th March 2001. The collected data were analyzed with the help of computer MSTATC software and the means were separated by LSD test.

\section{Results and Discussion}

Effect of variety

Performance of different potato varieties on the yield and quality of potato are presented in (Table I). It is revealed that the highest plants per (117.37) were recorded from Heera followed by Chamak. Other varieties also gave similar result. The variety Heera produced maximum tuber per plant (8.52). It might be due to its long stolon characters. Tuber produced by other varieties was very close. The highest tuber weight was recorded by variety Heera (51.03 g) followed by Chamak (49.64 g). It is established that fact potato varieties produced tuber with second growth in a condition of water deficiency leading to rise in soil temperature (Annon, 1998, Rashid, 1984; Hoque et. al. 2004). The

Table I. Yield and yield contributing characters of potato variety as affect by mulching under no tillage condition (Pooled).

\begin{tabular}{l|c|c|c|c|c}
\hline \multicolumn{1}{c|}{ Variety } & $\begin{array}{c}\text { Plant height } \\
(\mathrm{cm})\end{array}$ & Plant/plot & Tuber/plant & $\begin{array}{c}\text { Tuber weight } \\
(\mathrm{g})\end{array}$ & Yield (t/ha) \\
\hline Heera & 60.18 & 117.37 & 8.52 & 51.03 & 21.302 \\
Dhera & 55.47 & 116.37 & 8.00 & 49.15 & 19.276 \\
Diamont & 58.93 & 116.5 & 7.91 & 48.14 & 18.541 \\
Chamak & 57.12 & 117.0 & 7.29 & 49.64 & 17.638 \\
Cardinal & 56.87 & 116.87 & 7.60 & 49.52 & 18.237 \\
\hline CV(\%) & 3.69 & 0.32 & 2.02 & 1.46 & 2.26 \\
LSD (0.05) & 3.037 & 0.584 & 0.243 & 1.11 & 0.662 \\
\hline
\end{tabular}


lowest tuber per plant was recorded (48.14 g) in Diamont. These findings agreed with Hoque et al, (2004). Among the varieties tuber yield was ranged from 21.302-17.638 t/ha with an average on $19.0 \mathrm{t} / \mathrm{ha}$. The variety Heera produced higher tuber yield (21.30 t/ha), which was statistically different from other varieties. It might be due to higher number of tuber per plant and higher tuber weight.

\section{Effect of mulching material}

Effect of different mulching materials on the yield of potato is presented in (Table II). The maximum tuber per plant was recorded by mulching material of water hyacinth compare than rice straw. It implies that there were water stress because straw mulch could not cover the tubers properly for which there was less moisture in the soil. Tuber weights were higher in water hyacinth. Regarding yield it was found that when water hyacinth was used as mulching materials the tuber yield was maximum (20.26 t/ha). Reason might be behind that water hyacinth retained moisture in the soil for longer period, which was ultimately, increased tuber yield.

\section{Interaction effect of variety and mulching}

Interaction effect of different variety and mulching materials are presented in (Table III). All the varieties grown under water hyacinth produced higher yield except the variety Chamak. Chamak produced higher yield (17.76 t/ha) in rice straw mulching compare than water hyacinth mulching (17.5 t/ha). Water hyacinth gave higher tuber per plant and tuber weight. Another reason soil temperature under straw mulch was higher than that of water hyacinth. Maximum yield was recorded Heera variety (2.15 t/ha). This finding agreed with Hoque et al (2004). It implies that the variety Heera can produce good yield either any of mulching materials.

\section{Tuber Quality}

Tuber quality was affected by mulching and varietal performance, which were presented in (Table IV.) During grading of tuber it was found that small sized tubers ranged from $30.2 \%$ to $40.0 \%$ by weight and larged sized tubers ranged from $15.8 \%$ to $12 \%$ by weight. Maximum medium sized tubers were (50.2\%) produced in Heera under water hyacinth

Table II. Yield contributing characters of potato variety as affect by mulching under no tillage condition (Pooled value)

\begin{tabular}{l|c|c|c|c|c}
\hline \multicolumn{1}{c|}{$\begin{array}{c}\text { Mulching } \\
\text { material }\end{array}$} & $\begin{array}{c}\text { Plant } \\
\text { height }(\mathrm{cm})\end{array}$ & Plant/plot & Tuber/plant & $\begin{array}{c}\text { Tuber weight } \\
(\mathrm{g})\end{array}$ & Yield (t/ha) \\
\hline Water hyacinth & 58.80 & 117.05 & 8.11 & 50.44 & 20.264 \\
Rice straw & 57.65 & 116.70 & 7.65 & 48.55 & 18.064 \\
\hline
\end{tabular}


Table III. Interaction of mulching and varieties on the yield and yield attributes potato (Pooled)

\begin{tabular}{|c|c|c|c|c|c|c|}
\hline \multicolumn{2}{|c|}{ Treatment } & \multirow{2}{*}{$\begin{array}{c}\text { Plant height } \\
\text { (CM) }\end{array}$} & \multirow{2}{*}{ Plant/plot } & \multirow{2}{*}{ Tuber/plant } & \multirow{2}{*}{$\begin{array}{c}\text { Tuber weight } \\
\text { (g) }\end{array}$} & \multirow{2}{*}{ Yield (t/ha) } \\
\hline Mulch & Variety & & & & & \\
\hline \multirow{5}{*}{$\begin{array}{l}\text { Water } \\
\text { hyacinth }\end{array}$} & Heera & 61.72 & 118.25 & 8.99 & 52.31 & 23.155 \\
\hline & Dhera & 58.94 & 116.50 & 8.66 & 49.80 & 20.920 \\
\hline & Diamont & 59.12 & 116.50 & 8.18 & 48.79 & 19.367 \\
\hline & Chamak & 57.00 & 117.00 & 7.11 & 50.52 & 17.516 \\
\hline & Cardinal & 57.25 & 117.00 & 7.62 & 50.80 & 18.863 \\
\hline \multirow{5}{*}{$\begin{array}{l}\text { Rice } \\
\text { straw }\end{array}$} & Heera & 58.75 & 116.50 & 8.06 & 49.75 & 19.450 \\
\hline & Dhera & 57.00 & 116.0 & 7.52 & 48.50 & 17.632 \\
\hline & Diamont & 58.75 & 117.00 & 7.56 & 47.50 & 17.715 \\
\hline & Chamak & 57.25 & 117.25 & 7.46 & 48.75 & 17.760 \\
\hline & Cardinal & 56.00 & 116.75 & 7.57 & 48.25 & 17.612 \\
\hline $\mathrm{CV}(\%)$ & & 4.83 & 0.73 & 2.34 & 2.56 & 4.16 \\
\hline LSD (0.05) & & 4.078 & 1.235 & 0.267 & 1.837 & 1.14 \\
\hline
\end{tabular}

Table IV. Tuber quality as affected by mulching and variety of Lebukhali Patuakhali during rabi season ( Pooled value)

\begin{tabular}{l|l|c|c|c|c}
\hline \multicolumn{2}{c|}{ Treatment } & \multirow{2}{*}{$\begin{array}{c}\text { Green tuber } \\
\text { (by \%wt.) (g) }\end{array}$} & \multicolumn{3}{c}{ Grades of tubers by size (\%) } \\
\cline { 1 - 4 } Mulching & Variety & 5.2 & $428 \mathrm{~mm}$ & $28-55 \mathrm{~mm}$ & $>55 \mathrm{~mm}$ \\
\hline Water & Heera & 6.8 & 35.0 & 50.2 & 12.0 \\
hyacinth & Dhera & 6.2 & 34.2 & 48.3 & 15.6 \\
& Diamont & 6.8 & 32.2 & 47.5 & 14.5 \\
& Chamak & 6.3 & 30.2 & 47.2 & 15.4 \\
& Cardinal & 6.3 & 39.2 & 46.3 & 15.8 \\
\hline Rice & Heera & 7.5 & 34.2 & 48.2 & 12.3 \\
& Dhera & 7.3 & 33.5 & 46.3 & 14.3 \\
& Diamont & 7.2 & 32.5 & 45.2 & 14.1 \\
& Chamak & 7.1 & 30.4 & 46.1 & 13.7 \\
& Cardinal & & & 45.0 & 13.3 \\
\hline
\end{tabular}


mulching and minimum in Cardinal $45 \%$ of rice straw mulching. Medium size tubers are very important because they have more market value. Minimum green tuber was produced water hyacinth mulching and maximum was recorded in rice straw. It was revealed that water hyacinth covered potato tubers properly and sunlight cannot contact with tubers.

\section{Conclusion}

From the above invetigation it can be concluded that tubers of Heera can be planted under water hyacinth or rice straw mulch but better production under water hyacinth mulch under no tillage condition. So, water hyacinth can be used as mulching material while planting potato under no tillage condition. To avoid greening, thick water hyacinth mulch of 10-12 cm can be used.

\section{References}

Haq, A. S. M.A. Matin, M.A. (2006) A study of potato export from Bangladesh. Bangladesh J. Agril. Res. 31(2): 259-266

Rashid, M.M. (1999) Shabji Bijnan (in Bengali). Vegetable Production. 2nd edition. Rashid Publishing House, 94, Old DOHS, Dhaka1206. Pp: 141-142.

Hoque, M.A. (2001). Final report on Post Flood Rehabilitation and Adaptive Research Support Project, BARI, Munshiganj. BARI, Munshiganj and BARC, Dhaka. Pp: 28-29.
Anonymous, (2000) Bina Chashe Alu Utpadon (In Bengali). Potato Production with no tillage condition (a folder). Tuber Crops Research Centre, Bangladesh Agricultural Research Institute, Joydebpur, Gazipur.

Razzaque, M.A. Satter, M.A. Amin, M.S. Quayyum, M.I. Alam, M.S. (2000) Edited. Krishi Projukti Hatboi (In Bengali). Handbook on Agro-technology. 2nd Edition. Bangladesh Agricultural Research Institute, Joydebpur, Gazipur-1701, Bangladesh. Pp: 201-202.

Anonymous (1998). Annual Report of TCRSC, 1997-1998. Tuber Crops Research Sub Centre, Bangladesh Agricultural Research Institute, Munshiganj.

Rashid, M.M. (1984). Alur Chash (In Bengali). Cultivation of Potatoes. Second Edition. Bangla Acedamy, Dhaka, Bangladesh. Pp136.

Hoque, M.A. Islam, M.R. Faruquei, M.A.B. Ahmed, U. Khan, M.A.I. (2004). Yield and quality of potato as affected by variety and mulching under no tillage condition. $J$. Subtrop. Agric. Res. Dev. 2(2): 20-23.

Received :April 16, 2008;

Accepted : August 18, 2008. 
